Abstract-From late 2014 through 2017, fishery observers in the North Pacific Observer Program, National Marine Fisheries Service, were trained in the identification and sampling of skate egg cases to investigate the interactions between fisheries and skate nursery areas in the eastern Bering Sea. Trained observers identified and assessed 2887 egg cases in a wide range of fisheries across all gear types, with the majority of egg cases being encountered on vessels targeting deepwater species, such as the arrowtooth flounder (Atheresthes stomias), Greenland halibut (Reinhardtius hippoglossoides), Pacific cod (Gadus macrocephalus), and sablefish (Anoplopoma fimbria). A large proportion of the egg cases identified were reported on boats using bottom trawling gear, but an even greater proportion were reported on longliners. Egg cases identified represent 10 skate taxa. Over half $(67 \%)$ of them were identified as Alaska skate (Bathyraja parmifera), and $19 \%$ were identified as either Aleutian skate (B. aleuti$c a$ ) or Bering skate (B. interrupta). More than $42 \%$ of all the egg cases assessed were viable (contained a living skate); over $50 \%$ of egg cases of Alaska skate and of egg cases encountered on longliners were viable. The highest concentrations of egg cases generally were reported near known skate nursery areas, particularly in the Bering, Pribilof, and Pervenets Canyons.

Manuscript submitted 28 June 2018. Manuscript accepted 29 October 2018. Fish. Bull. 117:8-14 (2019).

Online publication date: 21 November 2018 doi: 10.7755/FB.117.1.2

The views and opinions expressed or implied in this article are those of the author (or authors) and do not necessarily reflect the position of the National Marine Fisheries Service, NOAA.

\title{
Interactions between fisheries and early life stages of skates in nursery areas of the eastern Bering Sea
}

\author{
Duane E. Stevenson \\ Gerald R. Hoff \\ James W. Orr \\ Ingrid Spies \\ Christopher N. Rooper \\ Email address for contact author: duane.stevenson@noaa.gov \\ Alaska Fisheries Science Center \\ National Marine Fisheries Service, NOAA \\ 7600 Sand Point Way NE \\ Seattle, Washington 98115-6349
}

Skates (Rajiformes) form an important and diverse component of the ichthyofauna in the eastern Bering Sea (EBS). At least 12 species of skates are currently known to occur in the EBS (Stevenson et al., 2007), and the overall biomass of skates in this region is currently estimated at about 600,000 metric tons (Ormseth, 2017). On the EBS shelf, the skate fauna is dominated by the Alaska skate (Bathyraja parmifera), which accounts for over $90 \%$ of the skate biomass at depths $<200 \mathrm{~m}$ (Stevenson et al., 2008). In the deeper waters of the EBS outer shelf and upper continental slope, skate diversity increases as other species, such as the Aleutian skate (B. aleutica), Bering $\operatorname{skate}^{1}(B$. interrupta), mud skate (B. taranetzi), Commander skate (B. lindbergi), and whiteblotched skate (B. maculata), are encountered more frequently (Hoff, 2016). The continental slope of the EBS is an area of particularly high skate diversity,

${ }^{1}$ We recognize Bathyraja kincaidii on the west coast of North America as a species distinct from $B$. interrupta in Alaska waters; therefore, we retain the common name Bering skate, rather than sandpaper skate, for this species (see Ebert, 2003; Stevenson et al., 2007). and as many as 7 species have been encountered in a single haul (Stevenson et al., 2008).

Skates are oviparous, depositing their eggs in egg cases on the seafloor. In the Bering Sea, several species of skates congregate in small, localized nursery areas along the outer continental shelf and upper slope to deposit their eggs (Hoff, 2008, 2010). These sites may reach densities of $800,000 \mathrm{eggs} / \mathrm{km}^{2}$, are occupied by skates continuously throughout the year, and have been persistently used by skates for decades (Hoff, 2010). For at least some species of skates, the incubation time from egg deposition to hatching may be 3-4 years (Hoff, 2008), and hatchlings are relatively large (14-25 cm in total length) and fully developed (Hoff, 2009). These early life history characteristics, combined with the adult characteristics of large size, slow growth, late maturation, and low fecundity, make skates particularly vulnerable to both natural and anthropogenic disturbances (Dulvy et al., 2000; Frisk et al., 2005; Matta and Gunderson, 2007).

Alaska's marine ecosystems are highly productive, supporting numerous fisheries for benthic and 
benthopelagic species, such as walleye pollock (Gadus chalcogrammus), Pacific cod (Gadus macrocephalus), sablefish (Anoplopoma fimbria), and several species of rockfishes (Scorpaenidae) and flatfish (Pleuronectidae). Although they are not targeted, significant numbers of skates are encountered as bycatch in a number of the fisheries of Alaska, particularly the longline fishery for Pacific cod (Stevenson and Lewis, 2010). These fisheries regularly encounter skate egg cases, in addition to adult and juvenile skates (senior author, personal observ.; North Pacific Observer Program ${ }^{2}$ ). Egg cases are brought to the surface when they are captured in trawl nets or entangled in longline gear. Egg cases captured during fishing operations are generally returned to the sea. Unknown are the proportion of captured egg cases that contain viable embryos and the mortality associated with viable eggs that are subjected to capture and subsequent release by fisheries.

At least 26 nursery areas for 6 species of skates have been identified in the EBS (Rooper et al., in press). These sites are located along the outer continental shelf and upper slope, at depths ranging from $\sim 150 \mathrm{~m}$ to 1069 m. In 2015, the North Pacific Fishery Management Council designated 6 of the known skate nursery areas in the EBS (Fig. 1) as habitat areas of particular concern (HAPC), suggesting that these areas "are rare and provide an important ecological function" (Federal Register, 2015). Although this designation did not provide any protection for these $6 \mathrm{HAPC}$, it included a recommendation that the National Marine Fisheries Service monitor these sites for potential effects of fishing. The overall goal of this study was to provide additional information on fishery interactions with skate egg cases and skate nursery areas in the EBS, by using data collected by fishery observers in the North Pacific Observer Program. Specifically, the objectives of this study were 1) to identify the species of skates for which fisheries encounter eggs, 2) to determine the proportion of skate eggs encountered by fisheries that are viable, and 3) to identify potentially unknown nursery areas by determining the location of viable skate eggs encountered by fisheries relative to documented skate nursery areas.

\section{Materials and methods}

All data used in this study were collected by fishery observers in the North Pacific Observer Program, which monitors commercial fishing activity in the federal waters of the U.S. exclusive economic zone of the

\footnotetext{
${ }^{2}$ North Pacific Observer Program. 2018. Unpubl. data. North Pac. Obs. Program, 7600 Sand Point Way NE, Seattle, WA 98115 .
}

North Pacific Ocean, Gulf of Alaska, Aleutian Islands, and EBS. All vessels over $12 \mathrm{~m}(40 \mathrm{ft})$ in length that participate in federally managed commercial groundfish fisheries are required to carry a fishery observer for at least a portion of their fishing activity. Observers record data on fishing effort and catch composition, using a variety of subsampling methods depending on gear type and logistical constraints, as detailed in the sampling manual produced annually by the program $\left(\mathrm{AFSC}^{3}\right.$ ). To the extent possible, observers identify sampled individuals of all federally managed groups (e.g., rockfish, flatfish, skate) to the species level and other species to the family level. Skate egg cases appearing in observer samples are counted and recorded simply as skate egg case unidentified, regardless of species or condition.

Data collection for this study was restricted to the EBS and occurred from 15 November 2014 through 15 November 2017. During this period, over 500 experienced observers were trained in the species-level identification of skate egg cases. Trainees were issued several tools for the identification of skate egg cases, including a dichotomous key, a picture guide, and a length-width chart. They were also given data forms, on which they were instructed to record observer name, gear type, cruise number, permit number, haul, date, species, total number non-viable, total number viable, and comments. An egg case was considered viable if it contained a yolk mass or a skate embryo in any

\footnotetext{
${ }^{3}$ AFSC (Alaska Fisheries Science Center). 2016. 2017 observer sampling manual, 585 p. Fish. Monit. Anal. Div., North Pac. Groundfish Obs. Program, Alaska Fish. Sci. Cent., Seattle, WA. [Available from website.]
} 
Table 1

Number of egg cases of skates identified by observers aboard commercial fishing vessels in the eastern Bering Sea from November 2014 through November 2017, by gear type and presumed target species.

\begin{tabular}{|c|c|c|c|c|c|c|c|c|c|}
\hline \multirow[b]{2}{*}{ Gear type } & \multicolumn{8}{|c|}{ Predominant (target) species } & \multirow[b]{2}{*}{ Total } \\
\hline & $\begin{array}{l}\text { Pacific } \\
\operatorname{cod}\end{array}$ & $\begin{array}{l}\text { Deepwater } \\
\text { flatfish } \\
\text { species }\end{array}$ & Sablefish & $\begin{array}{l}\text { Walleye } \\
\text { pollock }\end{array}$ & $\begin{array}{l}\text { Pacific } \\
\text { halibut }\end{array}$ & $\begin{array}{l}\text { Other } \\
\text { flatfish } \\
\text { species }\end{array}$ & $\begin{array}{c}\text { Rockfish } \\
\text { species }\end{array}$ & Other & \\
\hline Longline & 1514 & & 308 & 1 & 17 & 1 & & 27 & 1868 \\
\hline Bottom trawl & 3 & 612 & & 39 & 91 & 71 & 59 & 1 & 876 \\
\hline Pelagic trawl & & 5 & & 133 & & 2 & 1 & & 141 \\
\hline Pot & 1 & & 1 & & & & & & 2 \\
\hline Total & 1518 & 617 & 309 & 173 & 108 & 74 & 60 & 28 & 2887 \\
\hline
\end{tabular}

stage of development; an egg case was determined to be non-viable if it was empty or full of sediment. Observers trained for this project recorded species identifications and viability assessments of skate egg cases on data forms, and they turned in their forms during postcruise debriefing. Ultimately, these data forms were returned to the main office of the North Pacific Observer Program in Seattle.

Only species-level data recorded by project participants were used to create distribution maps for individual species. The position of each haul was determined by the deployment latitude and longitude recorded by the observer in the field. Because observers did not record the target species of commercial fishing operations, the predominant species was used to infer target species for each haul. Nonparametric Mann-Whitney $U$ tests were conducted to determine the significance of differences among proportions of egg cases that were viable.

\section{Results}

Fishery observers in the EBS identified and assessed the viability of 2887 skate egg cases from 408 hauls of commercial fishing vessels for this project (Fig. 2). Sampled hauls were distributed broadly across the continental shelf and upper slope, ranging in depth from 45 to $684 \mathrm{~m}$, but they were concentrated near the break between the shelf and slope. The number of egg cases in a single sampled haul ranged from 1 to 204 (mean: 5.4 egg cases), and as many as 3 species of skates were identified from egg cases sampled in a single haul.

Observers identified egg cases from a wide variety of fisheries and gear types, but over half of all egg cases identified for this study were encountered on longline vessels targeting Pacific cod (Table 1). Smaller numbers of egg cases were encountered on vessels using bottom trawling gear, particularly those targeting

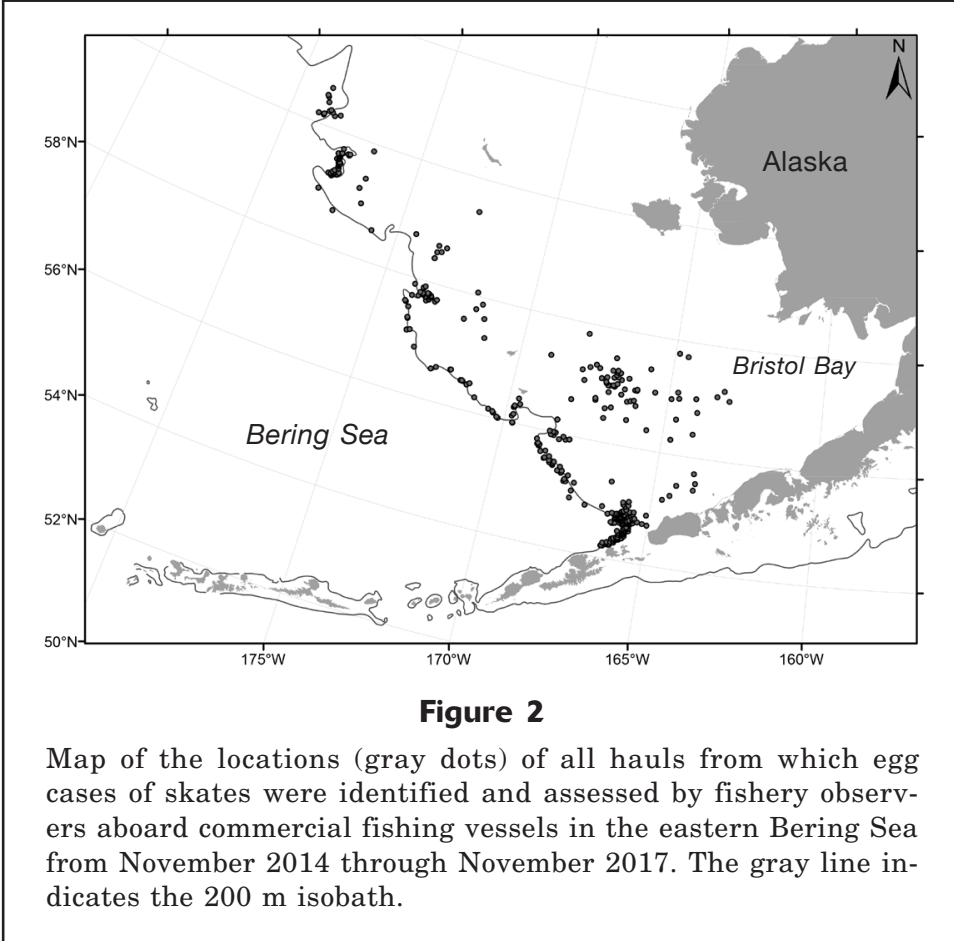

deepwater flatfish species (arrowtooth flounder, Atheresthes stomias, and Greenland halibut, Reinhardtius hippoglossoides), and on vessels using pelagic trawls and even pots.

Egg cases identified by observers represent 10 putative taxa (Table 2). Over $67 \%$ of egg cases were identified as Bathyraja parmifera, and the next most common taxa were $B$. aleutica $(12 \%)$ and $B$. interrupta (7\%). The other 7 taxa combined for the remaining $14 \%$ of the identified egg cases. The egg cases of Commander skate and whiteblotched skate are very similar and are extremely difficult to distinguish without magnification. Therefore, for the purposes of this study, the 2 species were combined into a single taxon. 


\section{Table 2}

Viability of egg cases of skates identified by observers aboard commercial fishing vessels in the eastern Bering Sea from November 2014 through November 2017. Viable egg cases contained a yolk mass or an embryo in some stage of development. Mean percentages of viable egg cases are presented with standard errors (SEs) in parentheses.

\begin{tabular}{lrrrr}
\hline Species & Empty & Viable & Viable (\%) & Total \\
\hline Bathyraja parmifera & 976 & 979 & $50.1(2.4)$ & 1955 \\
Bathyraja aleutica & 259 & 88 & $25.4(3.8)$ & 347 \\
Bathyraja interrupta & 157 & 46 & $22.7(4.8)$ & 203 \\
Bathyraja lindbergi/maculata & 153 & 61 & $28.5(6.7)$ & 214 \\
Bathyraja minispinosa & 92 & 36 & $28.1(6.9)$ & 128 \\
Bathyraja abyssicola & 16 & 7 & $30.4(7.9)$ & 23 \\
Bathyraja taranetzi & 6 & 3 & $33.3(16.7)$ & 9 \\
Raja rhina & 4 & 0 & 0 & 4 \\
Bathyraja trachura & 2 & 1 & $33.3(33.3)$ & 3 \\
Amblyraja hyperborea & 1 & 0 & 0 & 1 \\
Total & 1666 & 1221 & $42.3(1.8)$ & 2887 \\
& & & &
\end{tabular}

Approximately $42 \%$ of egg cases assessed by observers were classified as viable, although viability proportions were not uniform across species or gear type. For most species, viability proportions ranged from about $20 \%$ to $30 \%$ (Table 2), but the proportion for egg cases of Alaska skate was significantly higher $(P<0.0001)$. Among gear types, over half $(53.9 \%)$ of egg cases assessed on longline vessels were classified as viable (Table 3), but the percentages of egg cases that were viable for the 2 types of trawling gear were significantly lower $(P<0.0001)$. The sample sizes for several species and from boats using pot gear were too low to provide credible estimates of viability.

Most of the egg cases identified by observers as $B$. parmifera, B. aleutica, or B. interrupta were concentrated near the 6 nursery areas designated as HAPC. Egg cases of Alaska skate were the most broadly distributed, with high concentrations caught near the Bering 1, Pribilof, and Pervenets sites (Fig. 3A). Additional high concentrations were reported in the northern part of Pribilof Canyon and the southern part of Zhemchug Canyon. Egg cases of Aleutian skate were concentrated near the Bering 2 and Pervenets sites, with very few reported in other areas (Fig. 3B). Egg cases of Bering skate were encountered primarily near the Pervenets site, although some were also reported near the Bristol site and farther south in Bering Canyon (Fig. 3C). Observers identified large numbers (20 or more) of egg cases of Alaska skate in 18 separate hauls, but egg cases of Aleutian skate and Bering skate were recorded in large numbers much less frequently (1 and 2 hauls, respectively). The other 2 taxa that were identified in moderate numbers ( $B$. minispinosa and the taxon for individuals that could be $B$. lindbergi or $B$. maculata) were reported primarily from the southern rim of Bering Canyon, near the eastern Aleutian Islands.

\section{Table 3}

Viability by gear type for egg cases of skates identified and assessed by observers aboard commercial fishing vessels in the eastern Bering Sea from November 2014 through November 2017. Viable egg cases contained a yolk mass or an embryo in some stage of development. Mean percentages of viable egg cases are presented with standard errors (SEs) in parentheses.

\begin{tabular}{lrrcr}
\hline Gear type & Empty & Viable & Viable (\%) & Total \\
\hline Longline & 861 & 1008 & $53.9(2.7)$ & 1868 \\
Bottom trawl & 697 & 178 & $20.3(2.2)$ & 876 \\
Pelagic trawl & 106 & 35 & $24.8(4.5)$ & 141 \\
Pot & 2 & 0 & 0 & 2 \\
Total & 1666 & 1221 & $42.3(1.8)$ & 2887
\end{tabular}

\section{Discussion}

The results of this study indicate that the egg cases of a variety of skate species are regularly encountered in the commercial fisheries of Alaska. These encounters are most common in the canyon areas of the EBS, near the shelf break, at depths favored by skates for egg deposition (Hoff, 2008, 2010). Therefore, fisheries for relatively deepwater species, such as the arrowtooth flounder, Greenland halibut, Pacific cod, and sablefish, are more likely to encounter egg cases of skates than fisheries for relatively shallow-water species, such as walleye pollock and small flatfish species.

A somewhat surprising result of this study was the relatively high number of egg cases of skates reported on vessels fishing with longline gear. It is clear that a trawl sweeping the seafloor would collect the egg cases 

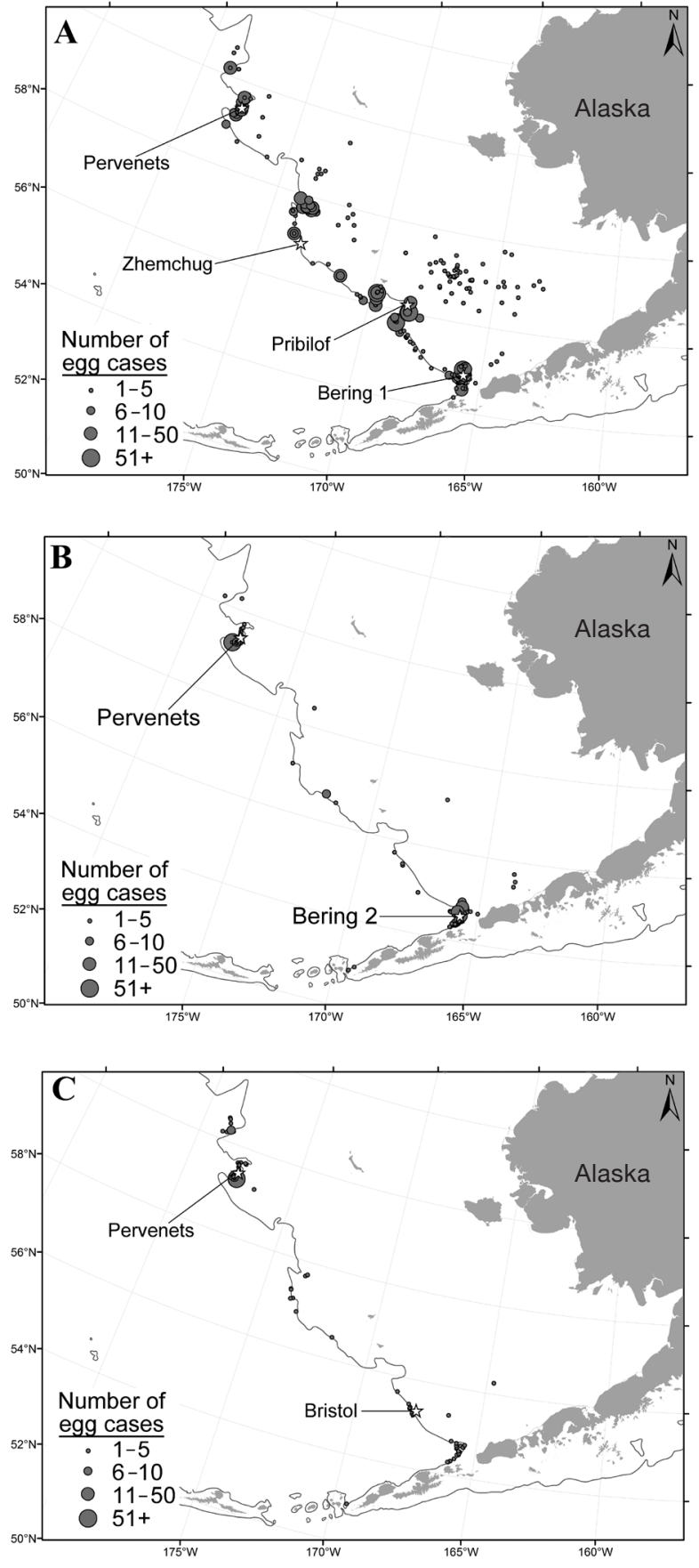

Figure 3

Maps of the geographic distribution of skate egg cases (gray circles) identified as (A) Alaska skate (Bathyraja parmifera), (B) Aleutian skate (B. aleutica), and (C) Bering skate (B. interrupta) by fishery observers aboard commercial fishing vessels in the eastern Bering Sea from November 2014 through November 2017. Open stars represent skate nursery areas designated as habitat areas of particular concern. The gray lines indicate the 200-m isobath. that it sweeps over; however, longline gear catches fish by attracting them to bite baited hooks, an action skate egg cases obviously cannot take. Still, although longline gear does not sweep the seafloor in the same way that trawling gear does, the groundline of a longline gear can move considerable distances across the bottom, under the influence of currents or large hooked fish and during gear retrieval (High ${ }^{4}$ ). As a result, sessile benthic organisms, such as corals and sponges, are commonly caught with longline gear (Durán Muñoz et al., 2011; Sampaio et al., 2012), and clearly skate egg cases fall into this category as well. In fact, the structure of egg cases-with long, curled horns on the ends and sticky byssal threads attached along the margins (Stevenson et al., 2007), adaptations that presumably keep them from being swept into less favorable areas by bottom currents-makes them ideally suited to cling to passing lines and hooks as well as to other egg cases. These results indicate that the effects of longline fishing on skate nursery areas may be similar to the effects of bottom trawling.

The relative abundance of skate egg cases identified to the species level by observers in this study is consistent with abundance patterns reported for adult skates in the EBS. The Alaska skate is by far the most abundant skate on the EBS shelf, accounting for $95 \%$ of the overall skate abundance at depths $<200 \mathrm{~m}$ (Stevenson et al., 2008; Stevenson and Lewis, 2010), and it is also by far the most common species of egg case identified by observers in this study. In the deeper waters of the continental shelf and upper continental slope, other species of skates, such as the Aleutian, Bering, Commander , and whiteblotched skates, become more abundant (Stevenson et al., 2008), and egg cases of these species were identified with regularity by observers in this project.

Both for the taxon that combined the Commander and whiteblotched skates and for B. minispinosa, over $80 \%$ of all the egg cases identified for this study were reported by a single observer on a single cruise, indicating the possibility that the abundance of these taxa may be inflated by misidentification. Likewise, a small number of egg cases were identified by observers as deepsea skate (B. abyssicola), and one egg case was identified as an Arctic skate (Amblyraja hyperborea, previously known as $A$. badia in the North Pacific). Both of those species are extremely rare in the Bering Sea and are found only in very deep water (Stevenson et al., 2007). Because none of these specimens were photographed or collected for species verification, the possibility remains that they could have been misidentified.

Less than half of the egg cases examined by observers in this study were classified as viable; therefore, most of the fishery interactions documented here involved empty egg cases. However, for one spe-

\footnotetext{
${ }^{4}$ High, W. L. 1998. Observations of a scientist/diver on fishing technology and fisheries biology. AFSC Proc. Rep. 98-01, 48 p. Alaska Fish. Sci. Cent., Natl. Mar. Fish. Serv., Seattle, WA. [Available from website.]
} 
cies (Alaska skate) and one gear type (longline), over half of the egg cases were assessed as viable. For all other species and gear types, the proportion of egg cases that were viable was no more than $30 \%$. This discrepancy may indicate that more fishing activity is occurring near the central portion of nursery areas used by Alaska skate than near those used by other species and that longline vessels are fishing closer to these areas than trawlers.

Hoff (2010) found that skate nursery areas generally consist of small areas with a high percentage of viable eggs surrounded by larger areas of predominantly (>70\%) empty egg cases; therefore, fishing activity near these high-density areas of nursery sites lead to interactions with higher proportions of viable eggs. However, this difference in viability proportion among gear types may be at least partially due to sampling artifacts. Egg cases captured in trawls may be subjected to very different forces than egg cases pulled up on a longline. Skate embryos can be expelled from their egg cases during capture and gear retrieval, and it can be difficult to determine whether a particular egg case was empty when encountered by the fishing gear or it had an embryo that was squeezed out at some point between capture and assessment. Therefore, without additional information on the relative expulsion rate of skate embryos from egg cases captured in different gear types, it is difficult to interpret the differences in viability rates presented here for egg cases captured with different gear types.

For viable egg cases, the mortality rate of skate embryos brought to the surface by fishing gear is unknown. In fact, discard mortality even for adult skates is not well known, although recent studies have begun to examine at least the short-term mortality of skate bycatch (see review by Ellis et al., 2017). Skate embryos of viable egg cases caught in fishing gear may suffer increased mortality for a number of reasons, including hook puncture, thermal stress, barotrauma, and crushing and concussive stress. Even if they are not injured directly, discarded egg cases may be displaced several kilometers or more from the nursery area, leaving them more vulnerable to predation and possibly exposing them to environmental conditions that are developmentally suboptimal or even lethal.

The majority of egg cases identified for this study were encountered near documented skate nursery areas, particularly the nursery areas designated as HAPC. Egg case densities at these sites can be as high as $800,000 \mathrm{eggs} / \mathrm{km}^{2}$ (Hoff, 2008, 2010), and nursery areas cover several square kilometers of seafloor. Therefore, fishing operations conducted near these sites are expected to encounter high concentrations of egg cases. Concentrations of egg cases for Alaska skate were reported in 2 additional areas well away from all nursery areas designated as HAPC. One of these areas of concentration, in the southern part of Zhemchug Canyon, is near a known nursery area for Alaska skate that has not been designated as an HPAC (Rooper et al., in press), likely explaining the abundance of egg cases in that area. The other area of concentration, in the northwestern part of Pribilof Canyon, is not near any known nursery area for Alaska skate, although 2 nursery areas for other species (B. minispinosa and the deepsea skate) are known in this area (Rooper et al., in press). This area of concentration of egg cases may indicate the presence of an additional nursery area for Alaska skate that has not yet been documented.

The overall number of egg cases reported by observers, and the locations of those encounters, indicate that fishing gear is being deployed in and around skate nursery areas, including those designated as HAPC. Clearly, skate embryos of viable egg cases caught in fishing gear are exposed to increased mortality rates. However, fishing activities have a variety of both shortand long-term effects on benthic marine communities (Auster et al., 1996; Auster and Langton, 1999), including the disturbance and redistribution of sediments and benthic organisms as well as the outright physical impacts on organisms contacted, but not captured by, fishing gear. In addition, although some types of benthic habitat are more vulnerable than others and some types of fishing gear are more damaging than others (Grabowski et al., 2014; Hiddink et al., 2017), the effects of any fishing gear on skate nursery areas have not been assessed. Therefore, fishing activity may be causing additional mortality to embryos not recorded in catch statistics, and the overall effects of fishery interactions with skate egg cases and nursery areas are still largely unknown.

Skate populations in the EBS appear to be healthy, and their overall biomass has been stable over the past 30 years (Hoff, 2006; Ormseth, 2017). However, significant community shifts in skate assemblages are not necessarily accompanied by declines in overall biomass (Dulvy et al., 2000; Stevens et al., 2000), and the slow growth and low reproductive potential exhibited by most skates (Ebert, 2005; Ebert et al., 2008) make them particularly vulnerable to environmental disturbance. Therefore, a cautious approach to the management and conservation of skate species is warranted. Previous work has documented the prevalence of adult skates commonly caught as bycatch in commercial fisheries (Stevenson and Lewis, 2010), and this study documents the interactions of fisheries with the early life history stages of skates and their nursery habitats. The mortality associated with fishing activities and the long-term effects of fishing pressure on the skate populations of the EBS are difficult to quantify. However, the potential for fishing activities to have significant detrimental effects on skate species exists, and this study emphasizes the need to continue monitoring these interactions, both with adults and with skates in early life history stages.

\section{Acknowledgments}

This research was supported by grant no. 1404 from the North Pacific Research Board. We thank the ob- 
servers, trainers, and staff of the North Pacific Observer Program for their cooperation and facilitation of this project. J. Ferdinand, R. Lauth, and B. Mason reviewed earlier drafts of this manuscript.

\section{Literature cited}

Auster, P. J., R. J. Malatesta, R. W. Langton, L. Watting, P. C. Valentine, C. L. S. Donaldson, E. W. Langton, A. N. Shepard, and W. G. Babb.

1996. The impacts of mobile fishing gear on seafloor habitats in the Gulf of Maine (Northwest Atlantic): implications for conservation of fish populations. Rev. Fish. Sci. 4:185-202. Crossref

Auster, P. J., and R. W. Langton.

1999. The effects of fishing on habitat. Am. Fish. Soc. Symp. 22:150-187.

Dulvy, N. K., J. D. Metcalfe, J. Glanville, M. G. Pawson, and J. D. Reynolds.

2000. Fishery stability, local extinctions, and shifts in community structure in skates. Conserv. Biol. 14:283-293. Crossref

Durán Muñoz, P., F. J. Murillo, M. Sayago-Gil, A. Serrano, M. Laporta, I. Otero, and C. Gómez.

2011. Effects of deep-sea bottom longlining on the Hatton Bank fish communities and benthic ecosystem, north-east Atlantic. J. Mar. Biol. Ass. U.K. 91:939-952. Crossref

Ebert, D. A.

2003. Sharks, rays, and chimaeras of California, 297 p. Univ. Calif. Press, Berkeley, CA.

2005. Reproductive biology of skates, Bathyraja (Ishiya$\mathrm{ma}$ ), along the eastern Bering Sea continental slope. J. Fish Biol. 66:618-649. Crossref

Ebert, D. A., W. D. Smith, and G. M. Cailliet.

2008. Reproductive biology of two commercially exploited skates, Raja binoculata and R. rhina, in the western Gulf of Alaska. Fish. Res. 94:48-57. Crossref

Ellis, J. R., S. R. McCully Phillips, and F. Poisson.

2017. A review of capture and post-release mortality of elasmobranchs. J. Fish Biol. 90:653-722. Crossref

Federal Register.

2015. Fisheries of the exclusive economic zone off Alaska; skates management in the Bering Sea and Aleutian Islands Management Area; habitat areas of particular concern. 80:1378-1379. [Available from website.]

Frisk, M. G., T. J. Miller, and N. K. Dulvy.

2005. Life histories and vulnerability to exploitation of elasmobranchs: inferences from elasticity, perturbation and phylogenetic analyses. J. Northwest Atl. Fish. Sci. 35:27-45. Crossref

Grabowski, J. H., M. Bachman, C. Demarest, S. Eayrs, B. P. Harris, V. Malkoski, D. Packer, and D. Stevenson.

2014. Assessing the vulnerability of marine benthos to fishing gear impacts. Rev. Fish. Sci. Aquacult. 22:142-155. Crossref

Hiddink, J. G., S. Jennings, M. Sciberras, C. L. Szostek, K. M. Hughes, N. Ellis, A. D. Rijnsdorp, R. A. McConnaughey, T. Mazor, R. Hilborn, et al.

2017. Global analysis of depletion and recovery of seabed biota after bottom trawling disturbance. Proc. Natl. Acad. Sci. U.S.A. 114:8301-8306. Crossref

Hoff, G. R.

2006. Biodiversity as an index of regime shift in the eastern Bering Sea. Fish. Bull. 104:226-237.

2008. A nursery site of the Alaska skate (Bathyraja parmifera) in the eastern Bering Sea. Fish. Bull. 106:233244.

2009. Skate Bathyraja spp. egg predation in the eastern Bering Sea. J. Fish Biol. 74:250-269. Crossref

2010. Identification of skate nursery habitat in the eastern Bering Sea. Mar. Ecol. Prog. Ser. 403:243-254. Crossref

2016. Results of the 2016 eastern Bering Sea upper continental slope survey of groundfish and invertebrate resources. NOAA Tech. Memo. NMFS-AFSC-339, 242 p.

Matta, M. E., and D. R. Gunderson.

2007. Age, growth, maturity, and mortality of the Alaska skate, Bathyraja parmifera, in the eastern Bering Sea. Environ. Biol. Fish. 80:309-323. Crossref

Ormseth, O. A.

2017. Partial assessment of the skate stock complex in the Bering Sea and Aleutian Islands In Stock assessment and fishery evaluation report for the groundfish resources of the Bering Sea/Aleutian Islands regions, $p$. 1045-1054. North Pacific Fishery Management Council, Anchorage, AK. [Available from website.]

Rooper, C. N., G. R. Hoff, D. E. Stevenson, J. W. Orr, and I. B. Spies.

In press. A predictive model for skate nursery habitat in the eastern Bering Sea. Mar. Ecol. Prog. Ser.

Sampaio, I., A. Braga-Henriques, C. Pham, O. Ocaña, V. de Matos, T. Morato, and F. M. Porteiro.

2012. Cold-water corals landed by bottom longline fisheries in the Azores (north-eastern Atlantic). J. Mar. Biol Ass. U.K. 92:1547-1555. Crossref

Stevens, J. D., R. Bonfil, N. K. Dulvy, and P. A. Walker.

2000. The effects of fishing on sharks, rays, and chimaeras (chondrichthyans), and the implications for marine ecosystems. ICES J. Mar. Sci. 57:476-494. Crossref

Stevenson, D. E., and K. A. Lewis.

2010. Observer-reported skate bycatch in the commercial groundfish fisheries of Alaska. Fish. Bull. 108:208-217.

Stevenson, D. E., J. W. Orr, G. R. Hoff, and J. D. McEachran.

2007. Field guide to sharks, skates, and ratfish of Alaska, 85 p. Alaska Sea Grant Coll. Prog., Univ. Alaska Fairbanks, Fairbanks, AK.

2008. Emerging patterns of species richness, diversity, population density, and distribution in the skates (Rajidae) of Alaska. Fish. Bull. 106:24-39. 